\title{
Teaching NeuroImages: Retinopathy in spinocerebellar ataxia type 3
}

Fábio A. Nascimento, MD, Matheus G. Ferreira, MD, Naoye Shiokawa, MD, Mario T. Sato, MD, PhD, and Hélio A.G. Teive, MD, PhD

\section{Neurology ${ }^{\circledR}$ 2020;94:e2283-e2284. doi:10.1212/WNL.0000000000009484}

Figure 1 Retinography, left eye

\section{Correspondence}

Dr. Nascimento

nascimento.fabio.a@gmail.com

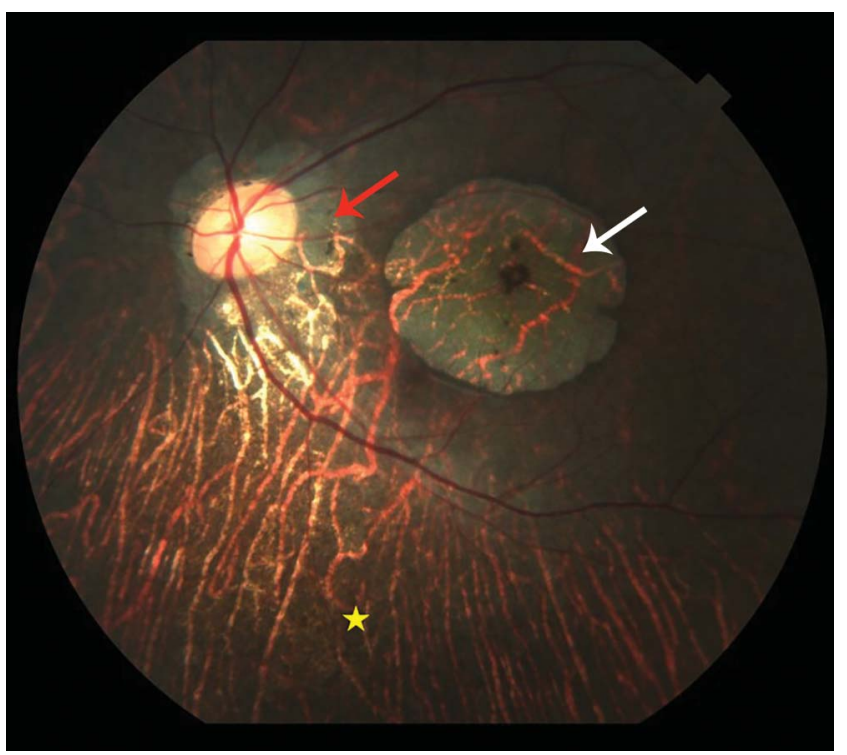

Peripapillary chorioretinal atrophy (red arrow), macular atrophy (white arrow), and extensive loss of retinal pigment epithelium in the lower retinal periphery (star).

A 17-year-old African Brazilian woman presented with a 1-year history of progressive ataxia, dysarthria, and decreased visual acuity. Family history was remarkable for multiple relatives with similar motor symptoms but no visual complaints. Examination showed upward gaze palsy, dysarthria, ataxia, and increased tone and reflexes. Fundoscopic examination and subsequent optical coherence tomography revealed bilateral atrophic maculopathy (figures 1 and 2). Genetic testing confirmed the diagnosis of spinocerebellar ataxia type 3 (SCA3) by revealing abnormal CAG repeats in the ATXN3 gene-the pathologic allele had 68 repeats and the normal allele 14 repeats.

Retinopathy, a typical finding in spinocerebellar ataxia type $7,{ }^{1}$ has rarely been associated with SCA3. ${ }^{2-4}$ Further studies should elucidate this association, thereby possibly expanding the phenotypic spectrum of SCA3.

\section{Study funding}

No targeted funding reported.

From the Department of Neurology (F.A.N.), Baylor College of Medicine, Houston, TX; and Division of Neurology (M.G.F., H.A.G.T.), Department of Internal Medicine, and Department of Ophthalmology (N.S., M.T.S.), Universidade Federal do Paraná, Curitiba, Brazil.

Go to Neurology.org/N for full disclosures. Funding information and disclosures deemed relevant by the authors, if any, are provided at the end of the article. 
Figure 2 Optical coherence tomography, right eye

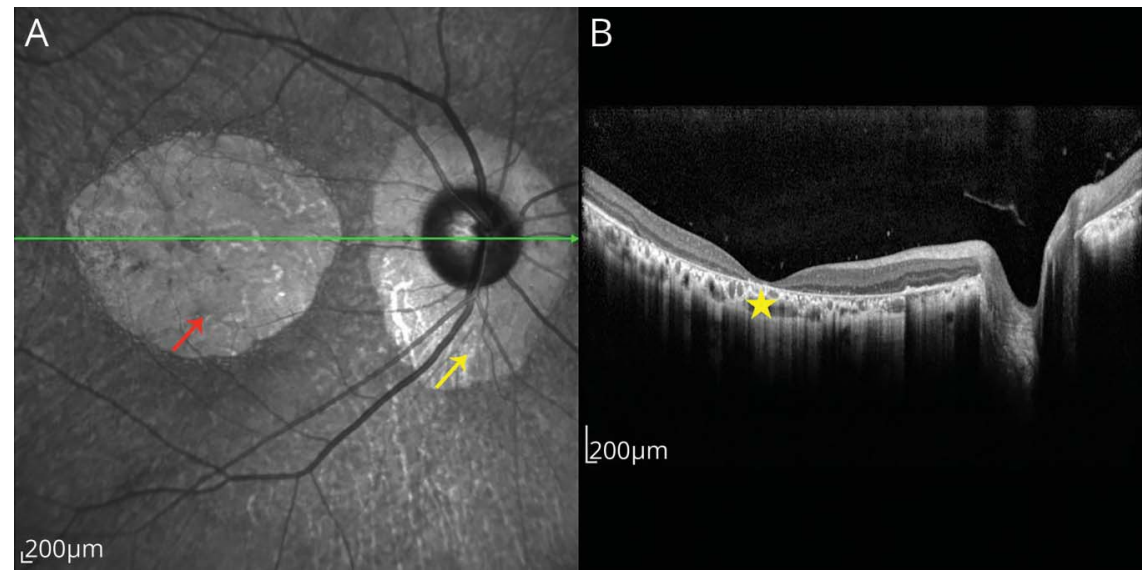

(A) Near-infrared light shows macular atrophy (red arrow) and peripapillary chorioretinal atrophy (yellow arrow). (B) Complete foveal atrophy, loss of deep macular layers within the atrophic topography, and loss of peripapillary retinal pigment epithelium (star).

\section{Disclosure}

F.A. Nascimento is a member of the Neurology ${ }^{\circledR}$ Resident \& Fellow Section Editorial Team. M.G. Ferreira, N. Shiokawa, M.T. Sato, and H.A.G. Teive report no relevant disclosures. Go to Neurology.org/ $\mathrm{N}$ for full disclosures.

\begin{tabular}{lll}
\hline Appendix & Authors & \\
\hline Name & Location & Contribution \\
\hline $\begin{array}{l}\text { Fábio A. } \\
\text { Nascimento, } \\
\text { MD }\end{array}$ & $\begin{array}{l}\text { Baylor College of } \\
\text { Medicine, } \\
\text { Houston, TX }\end{array}$ & $\begin{array}{l}\text { Designed study, analyzed and } \\
\text { interpreted the data, drafted the } \\
\text { manuscript }\end{array}$ \\
\hline $\begin{array}{l}\text { Matheus G. } \\
\text { Ferreira, MD }\end{array}$ & $\begin{array}{l}\text { Universidade } \\
\text { Federal do Paraná, }\end{array}$ & $\begin{array}{l}\text { Designed study, analyzed and } \\
\text { interpreted the data, drafted the } \\
\text { manuscript }\end{array}$ \\
\hline $\begin{array}{l}\text { Naoye } \\
\text { Shiokawa, } \\
\text { MD }\end{array}$ & $\begin{array}{l}\text { Eniversidade } \\
\text { Federal do Paraná, } \\
\text { Curitiba, Brazil }\end{array}$ & $\begin{array}{l}\text { Analyzed and interpreted the } \\
\text { data, revised the manuscript }\end{array}$ \\
\hline
\end{tabular}

\section{Appendix (continued)}

\begin{tabular}{lll}
\hline Name & Location & Contribution \\
\hline $\begin{array}{l}\text { Mario T. } \\
\begin{array}{l}\text { Sato, MD, } \\
\text { PhD }\end{array}\end{array}$ & $\begin{array}{l}\text { Universidade } \\
\text { Federal do Paraná, } \\
\text { Curitiba, Brazil }\end{array}$ & $\begin{array}{l}\text { Analyzed and interpreted the } \\
\text { data, revised the manuscript }\end{array}$ \\
\hline $\begin{array}{l}\text { Hélio A.G. } \\
\text { Teive, MD, } \\
\text { PhD }\end{array}$ & $\begin{array}{l}\text { Universidade } \\
\text { Federal do Paraná, } \\
\text { Curitiba, Brazil }\end{array}$ & $\begin{array}{l}\text { Designed and conceptualized } \\
\text { study, analyzed and interpreted } \\
\text { the data, revised the manuscript, } \\
\text { supervised study, final approval }\end{array}$ \\
\end{tabular}

\section{References}

1. Teive HAG, Ashizawa T. Primary and secondary ataxias. Curr Opin Neurol 2015;28: 413-422.

2. Isashiki $\mathrm{Y}$, Kii $\mathrm{Y}$, Ohba N, Nakagawa M. Retinopathy associated with Machado-Joseph disease (spinocerebellar ataxia 3) with CAG trinucleotide repeat expansion. Am J Ophthalmol 2001;131:808-810.

3. Durr A, Stevanin G, Cancel G, et al. Spinocerebellar ataxia 3 and Machado-Joseph disease: clinical, molecular, and neuropathological features. Ann Neurol 1996;39: 490-499.

4. Alvarez G, Rey A, Sanchez-Dalmau FB, et al. Optical coherence tomography findings in spinocerebellar ataxia-3. Eye 2013;27:1376-1381. 


\section{Neurology}

\section{Teaching NeuroImages: Retinopathy in spinocerebellar ataxia type 3}

Fábio A. Nascimento, Matheus G. Ferreira, Naoye Shiokawa, et al.

Neurology 2020;94;e2283-e2284 Published Online before print April 24, 2020

DOI 10.1212/WNL.0000000000009484

This information is current as of April 24, 2020

\section{Updated Information \&} Services

References

Subspecialty Collections

Permissions \& Licensing

Reprints including high resolution figures, can be found at: http://n.neurology.org/content/94/21/e2283.full

This article cites 4 articles, 0 of which you can access for free at: http://n.neurology.org/content/94/21/e2283.full\#ref-list-1

This article, along with others on similar topics, appears in the following collection(s):

Pupils

http://n.neurology.org/cgi/collection/pupils

Spinocerebellar ataxia

http://n.neurology.org/cgi/collection/spinocerebellar_ataxia

Information about reproducing this article in parts (figures,tables) or in its entirety can be found online at:

http://www.neurology.org/about/about_the_journal\#permissions

Information about ordering reprints can be found online:

http://n.neurology.org/subscribers/advertise

Neurology ${ }^{\circledR}$ is the official journal of the American Academy of Neurology. Published continuously since 1951, it is now a weekly with 48 issues per year. Copyright () 2020 American Academy of Neurology. All rights reserved. Print ISSN: 0028-3878. Online ISSN: 1526-632X.

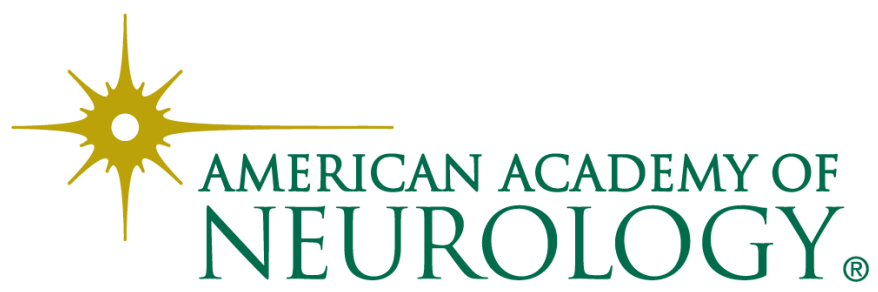

